University of Nebraska - Lincoln

DigitalCommons@University of Nebraska - Lincoln

2006

The Geochemical Record of the Last 17,000 Years in the Guaymas

Basin, Gulf of California

Walter E. Dean

U.S. Geological Survey, MS 980 Federal Center, Denver, CO 80225, USA

Follow this and additional works at: https://digitalcommons.unl.edu/usgsstaffpub

Part of the Earth Sciences Commons

Dean, Walter E., "The Geochemical Record of the Last 17,000 Years in the Guaymas Basin, Gulf of California" (2006). USGS Staff -- Published Research. 303.

https://digitalcommons.unl.edu/usgsstaffpub/303

This Article is brought to you for free and open access by the US Geological Survey at DigitalCommons@University of Nebraska - Lincoln. It has been accepted for inclusion in USGS Staff -- Published Research by an authorized administrator of DigitalCommons@University of Nebraska - Lincoln. 


\title{
The geochemical record of the last 17,000 years in the Guaymas Basin, Gulf of California
}

\author{
Walter E. Dean * \\ U.S. Geological Survey, MS 980 Federal Center, Denver, CO 80225, USA
}

Received 13 April 2005; received in revised form 24 January 2006; accepted 8 February 2006

\begin{abstract}
Sediments deposited on the western slope of the Guaymas Basin in the central Gulf of California are composed predominantly of detrital clastic material and biogenic silica (biopal), with minor organic material (average of $2.8 \%$ organic carbon) and calcium carbonate. The $\mathrm{CaCO}_{3}$ is derived from calcareous plankton and is highly variable ranging from $0 \%$ to $16 \%$. In general, the $\mathrm{CaCO}_{3}$ content of the sediments varies inversely with the biopal content, reflecting the relative abundance of calcareous and siliceous plankton in the photic zone. Siliceous plankton dominate when winds are predominantly out of the northwest producing strong upwelling. Calcareous plankton indicates weak southeasterly winds that bring warm, tropical Pacific surface water into the Gulf. Based mainly on relative abundances of biopal and $\mathrm{CaCO}_{3}$, the sediments deposited over the last 17,000 years in the western Guaymas Basin can be divided into five intervals. In general, the sediments in the intervals with high biopal and low $\mathrm{CaCO}_{3}$ are laminated, but this is not always true. Unlike most other continental margins of the world with well-developed oxygen minimum zones where highest concentrations of organic carbon and redox-sensitive trace metals occur in laminated sediments, the laminated sediments on the anoxic slope of the western Guaymas Basin do not always have the highest concentrations of organic carbon and trace metals such as Mo and Cd.

Published by Elsevier B.V.
\end{abstract}

Keywords: Calcium carbonate; Organic carbon; Cadmium; Molybdenum; Gulf of California

\section{Introduction and background}

The Gulf of California is an actively growing ocean basin, created over the last 4 million years by sea-floor spreading (Moore, 1973). The Guaymas Basin is a deep, semi-enclosed basin that formed as a result of this spreading (Fig. 1). There are several potential sediment sources to the Gulf of California. Five major rivers drain the volcanic rocks of the west slope of the Sierra Madre Occidental: Rios Sonora, Matape, Yaqui, Mayo, and Fuerte (Fig. 1). However, today much of the sediment in

* Tel.: +1 303236 5760; fax: +1 3032365349 .

E-mail address: dean@usgs.gov. these rivers is trapped in dams built along the rivers since 1940 (Baumgartner et al., 1991). The lower Colorado River drains sedimentary rocks of the Colorado Plateau, but today much of its sediment load also is deposited behind dams in Lake Powell and Lake Mead. Fine-grained terrigenous sediments from the Colorado River are mainly confined to the northern Gulf and do not appear to be escaping in significant amounts to the central Gulf region (Baba et al., 1991).

Based on a factor analysis of major-element contents of bulk sediment from 87 localities throughout the Gulf, Baba et al. (1991) identified a terrigenous factor that accounts for $80-90 \%$ of the total sedimentation along the eastern margin of the central and southern Gulf. 


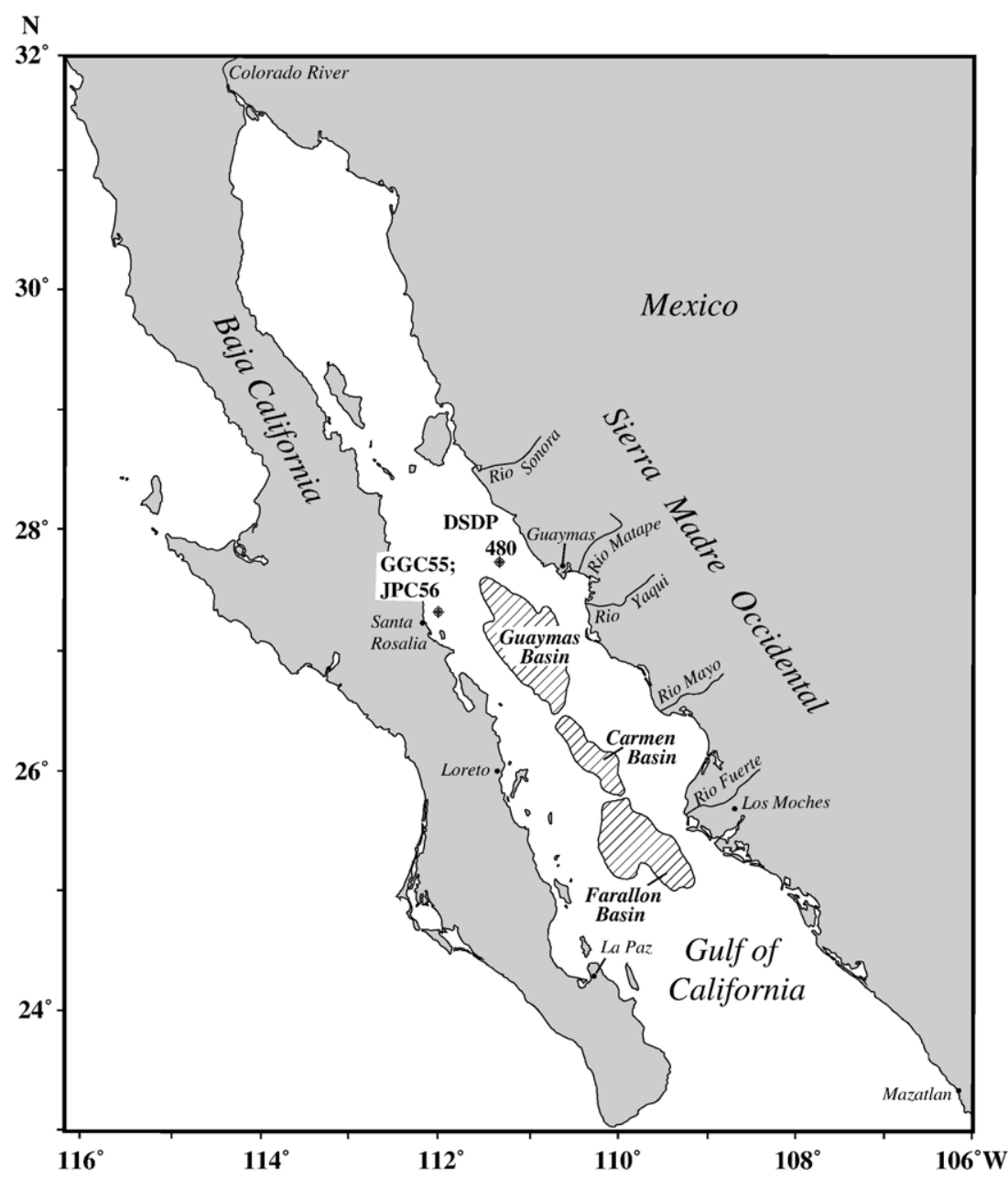

Fig. 1. Map of western Mexico, the Gulf of California, and Baja California showing locations of cores described in this paper. Enclosed basins of the central Gulf are shown by the diagonally lined areas.

Baba et al. (1991) also analyzed the mineralogy of samples from the Colorado River and coastal rivers of Mexico. Samples from the northern drainages had the highest quartz/feldspar ratios reflecting felsic sedimentary, plutonic, and metamorphic sources. Sediments from rivers draining the Sierra Madre into the central Gulf had the lowest quartz/feldspar ratios reflecting mafic volcanic sources. The Baja California peninsula is low lying with few rivers and is not considered to be a major sediment source (Baba et al., 1991).

The Gulf of California is characterized by marked seasonal changes in circulation and productivity driven by changes in atmospheric circulation over the eastern North Pacific and the adjacent North American continent. Winter conditions are characterized by strong northwesterly winds that transport water out of the Gulf, and produce upwelling and associated high organic productivity (Thunell et al., 1994; Thunell, 1998). During the summer, a low-pressure cell is established over Arizona that drives the southwestern monsoon and produces weak southerly winds over the Gulf and reduced organic productivity. Surface waters flow into the Gulf from the Pacific at this time including Tropical Surface Water and Subtropical Subsurface Water (Bray, 1988). Below these seasonally varying surface-water masses is oxygen-deficient North Pacific Intermediate Water (NPIW), which flows into the Gulf at water depths between 500 and $1000 \mathrm{~m}$ and establishes an oxygen minimum zone (OMZ) at those depths (Bray, 1988; Thunell, 1998). Summer is also the rainy season and organic productivity in the Gulf is low. Maximum precipitation (average of $70 \%$ of annual) usually occurs in August and September. A comparable high percentage of discharge of the three main rivers draining into 
the central Gulf (Rios Yaqui, Mayo, and Fuerte, Fig. 1) occurs during this 3-month period (Baumgartner et al., 1991).

The strong seasonality of rainfall, river discharge, circulation, and productivity in the Gulf should have a profound effect on sedimentation there. There should also be considerable variation in sedimentation driven by interannual and decadal events such as El Niños, La Niñas, and the Pacific Decadal Oscillation (PDO), as well as longer-term climatic and oceanic events. Seasonal variations are obvious in sediments within the OMZ, which are characterized by seasonal laminations (varves; Calvert, 1966; Baumgartner et al., 1991). The light-colored laminae consist mainly of diatom-rich biogenic sediment deposited from late fall to spring (Calvert, 1966; Baumgartner et al., 1991; Thunell, 1998). The dark laminae contain more detrital clastic material, and represent predominantly summer deposition.

The main purpose of this investigation was to determine if there were any geochemical signatures of past organic productivity and changes in redox conditions in this anoxic basin over the last 17,000years during the transition from global glacial conditions to present interglacial conditions (Holocene). The paleoceanographic and paleoclimatic framework on which to hang the geochemical results is well established in published reports by Calvert (1966), Schrader and Baumbartner (1983), Keigwin and Jones (1990), Sancetta (1995), Pride et al. (1999), Keigwin (2002), and Barron et al. (2004, 2005).

\section{Materials and methods}

Giant gravity core (GGC) 55 and jumbo piston core (JPC) 56 are two of a series of paired gravity and piston cores that were collected in July 1990 on $R / V$ Atlantis II cruise 125/8. These two cores were collected on the western slope of the Guaymas Basin, GGC55 at $27^{\circ} 28.22^{\prime} \mathrm{N}, 112^{\circ} 6.33^{\prime} \mathrm{W}$ in a water depth of $820 \mathrm{~m}$, and JPC56 at $27^{\circ} 28.16^{\prime} \mathrm{N}, 112^{\circ} 6.26^{\prime} \mathrm{W}$ in a water depth of $818 \mathrm{~m}$ (Fig. 1). Both cores were sampled at $10-\mathrm{cm}$ intervals for geochemical and diatom analyses.

The samples were analyzed for 40 major, minor, and trace elements by inductively coupled, argonplasma, atomic emission spectrometry (ICP-AES; Briggs, 2002), Rock standards (USGS) were included with the sediment samples, and $10 \%$ of the samples were duplicated. The precision, determined by analyzing rock standards and duplicate sediment samples, is better than $10 \%$, and usually is better than $5 \%$, at a concentration of 10 times the limit of detection. Only the results of analyses of aluminum (Al) as a proxy for detrital clastic material, cadmium $(\mathrm{Cd})$ as a proxy for organic productivity, and molybdenum (Mo) as a proxy for anoxia will be discussed in this report. Most of the other elements are associated with the detrital clastic fraction.

Dried samples were analyzed for weight percentages of total carbon (TC) and inorganic carbon (IC) by coulometric titration of carbon dioxide following extraction from the sediment by combustion at $950^{\circ} \mathrm{C}$ and acid volatilization, respectively (Engleman et al., 1985). Percent organic carbon (OC) was calculated as the difference (TC-IC), and percent $\mathrm{CaCO}_{3}$ was calculated as

$\mathrm{CaCO}_{3}=\mathrm{IC} / 0.12$,

where 0.12 is the fraction of carbon in $\mathrm{CaCO}_{3}$. The accuracy and precision of this method, determined from hundreds of replicate standards, usually are better than $0.10 \mathrm{wt} . \%$ for both TC and IC.

Values of biogenic silica and the basic calibrated radiocarbon age model are from Pride et al. (1999). Keigwin (2002) modified the basic age model of Pride et al. (1999) by applying a different reservoir correction, and this modified age model is used here. All ages are given in thousands of calendar years (kiloannum or ka). The biogenic silica data and measured values of dry bulk density (DBD in $\mathrm{g} / \mathrm{cm}^{3}$ ) are available online through the World Data Center-A for Paleoclimatology, NOAANGDC, Boulder, Colorado. Bulk-sediment mass accumulation rates (MAR in $\mathrm{g} / \mathrm{cm}^{2} / \mathrm{ky}$ ) were calculated as the product of $\mathrm{DBD}$ and interval sedimentation rate in $\mathrm{cm} / \mathrm{ky}$.

\section{Results}

Summary statistics for concentrations of $\mathrm{Al}, \mathrm{Cd}, \mathrm{Mo}$, $\mathrm{OC}, \mathrm{CaCO}_{3}$, and biopal in samples from cores GGC55 and JPC56 are given in Table 1. Concentrations of Al, $\mathrm{Cd}$, and Mo in average upper continental crust (UCC) and average deep-sea clay (DSC) also are given for comparison. Total organic matter content, as determined by loss on ignition at $550^{\circ} \mathrm{C}$, in marine sediments usually is about twice the total organic carbon content (W. Dean, unpublished data). Therefore, the average OC content of $2.8 \%$ translates to an average organic matter content of about $5.6 \%$. Organic matter accumulating in the present-day Guaymas Basin is predominantly of marine origin (Thunell, 1998; Pride et al., 1999). The $\mathrm{CaCO}_{3}$ content is low and highly variable, with an average of $5.5 \%$ but with a coefficient of variation of $80 \%$. Of the total of 209 samples, 39 contained $<1.0 \%$ 
Table 1

Summary statistics of elemental analyses for cores GGC55 and JPC56

\begin{tabular}{llllcll}
\hline Element & Mean & $\begin{array}{l}\text { Standard } \\
\text { deviation }\end{array}$ & Minimum & Maximum & $\begin{array}{l}\text { Average } \\
\text { UCC }\end{array}$ \\
\hline$\% \mathrm{Al}$ & 5.1 & 0.8 & 2.7 & 6.6 & 7.7 & 9.1 \\
ppm Cd & 2.7 & 1.4 & 1.0 & 11.0 & 1.4 & \\
ppm Mo & 10 & 4 & 1.85 & 21 & \\
$\% \mathrm{OC}$ & 2.8 & 0.6 & 0 & 4.9 & \\
$\% \mathrm{CaCO}_{3}$ & 5.5 & 4.4 & 8.1 & 45.4 & \\
$\%$ Biopal & 26 & 9.1 & & & \\
\hline
\end{tabular}

UCC, average upper continental crust (Wedepohl, 1995).

DSC, average deep sea clay (Chester, 1990).

$\mathrm{CaCO}_{3}$. Biopal is a major component of the sediments in these cores (average of $26.3 \%$, Table 1) as it is in sediments throughout the Gulf (e.g., Sancetta, 1995). Organic matter and $\mathrm{CaCO}_{3}$ are minor but important components, which leaves terrigenous aluminosilicates (detritus) as the other major component. A simple calculation assuming that the detrital material entering the Guaymas Basin has the same aluminum concentration as UCC (7.7\%; Table 1), gives an average detrital fraction in these two cores of $66 \%$.

Concentrations of $\mathrm{Cd}$ and Mo are extremely low in the earth's crust and the elevated concentrations found in the Gulf sediments (Table 1) must come from the water column. For $\mathrm{Cd}$ and Mo, it is obvious from Table 1 that any sediment containing more than about $0.1 \mathrm{ppm}$ $\mathrm{Cd}$ or $1 \mathrm{ppm} \mathrm{Mo}$ is in "excess" relative to the detrital (lithogenic) fraction (e.g., UCC). Average deep-sea clay contains both biogenic and hydrogenous components and, therefore, will contain higher than lithogenic concentrations of $\mathrm{Cd}$ and Mo (Table 1).

\section{Discussion}

\subsection{Element associations}

In marine sediments, most major elements, especially aluminum (Al), potassium (K), and titanium (Ti), are derived from detrital sources. Silica ( $\mathrm{Si})$ and calcium $(\mathrm{Ca})$ can be derived from detrital or biogenic sources. Certain trace elements in marine sediments, such as uranium (U), vanadium (V), nickel $(\mathrm{Ni})$, copper $(\mathrm{Cu})$, zinc $(\mathrm{Zn}), \mathrm{Cd}$, and $\mathrm{Mo}$, are concentrated in OC-rich sediments where sulfate reduction has occurred (e.g., Jacobs et al., 1985; Emerson and Huested, 1991; Crusius et al., 1996). These elements may have two non-terrigenous sources: (1) a biogenic source represented by trace elements taken up mostly in the photic zone by phytoplankton, and (2) a hydrogenous source derived from bottom water or sediment pore water by adsorption and precipitation reactions (Piper and Dean, 2002).

As a measure of sulfate reducing conditions, I focus on Mo in this study because of the elements for which I have data, it is the diagnostic element in sediments that accumulate under seawater sulfate-reducing conditions (Bruland, 1983; Jacobs et al., 1985; Emerson and Huested, 1991; Piper, 1994; Crusius et al., 1996, Piper and Dean, 2002). Piper and Dean (2002) calculated that hydrogenous Mo MAR contributed $97 \%$ of the total Mo MAR in surface sediments in the anoxic Cariaco Basin. Zheng et al. (2000b) found that in the Santa Barbara Basin, formation of hydrogenous Mo requires dissolved oxygen (DO) concentrations of $<3 \mu \mathrm{mol} / \mathrm{kg}$, so that strict bottom-water anoxia may not be required for the accumulation of hydrogenous Mo. In many marine settings, elevated concentrations of Mo (above $1 \mathrm{ppm}$ ) usually are associated with laminated sediments, another indicator of low-DO bottom-water conditions. Elevated concentrations of $\mathrm{Cd}$ (above $0.1 \mathrm{ppm}$ ) also might be used as a geochemical indicator of low-DO bottomwater conditions. However, because $\mathrm{Cd}$, along with $\mathrm{Cu}$, $\mathrm{Ni}$, and $\mathrm{Zn}$, are found in high concentrations in plankton (Collier and Edmond, 1984; Brumsack, 1986) it more likely has a biogenic source. Nameroff et al. (2002) found that most of the $\mathrm{Cd}$ in surface sediments on the Mazatlan margin could be attributed to input from plankton (nonlithogenic particulates in sediment traps). Piper and Dean (2002) found that $86 \%$ of the total Cd in Cariaco Basin sediments was from phytoplankton. Therefore, the concentration of $\mathrm{Cd}$ can be used, with some caution, as a qualitative measure of organic productivity.

Concentrations of $\mathrm{Mo}$ and $\mathrm{Cd}$ in these two cores are in excess of those in UCC (Table 1). In most OC-rich sediments, there is a strong correlation between Mo and Cd with OC (e.g., Piper and Dean, 2002), but in these Guaymas Basin sediments, Mo and Cd concentrations 
do not correlate with those of $\mathrm{Al}$ or $\mathrm{OC}$, which suggests that $\mathrm{Mo}$ and $\mathrm{Cd}$ are not associated with either the detrital or organic fractions. This is highly unusual, because sediments deposited within the OMZ on the open slope of northern Mexico off Mazatlan, just south of the Gulf of California, have concentrations of Mo and Cd that are highly correlated with those of OC (Nameroff et al., 2004).

\subsection{Down-core variations}

The variations in the concentrations and MARs of the two major components (\% biopal and \% detrital, represented by $\% \mathrm{Al})$ and two minor components $(\%$ $\mathrm{CaCO}_{3}$ and $\%$ organic matter, represented by $\%$ OC) are shown versus depth in Fig. 2. Radiocarbon ages (from Keigwin, 2002) are shown along the depth axis for $\%$ biopal (Fig. 2C). The most obvious feature of these plots is the decrease in MARs with decreasing age of all components, reflecting the decrease in bulk-sediment MAR, mainly due to a decrease in sedimentation rate from $>300 \mathrm{~cm} / \mathrm{ky}$ at the bottom of core JPC56 to $<100 \mathrm{~cm} / \mathrm{ky}$ at the top of core GGC55 (Pride et al., 1999).

Another obvious feature in Fig. 2 is the antithetic relation between \% biopal (Fig. 2C) and \% $\mathrm{Al}$ (Fig. 2D), which is to be expected in an essentially two-component system of biopal and terrigenous detritus where one component dilutes the other. Pride et al. (1999) interpreted periods of increased biopal content as representing times when diatoms were contributing significantly to overall sedimentation. They used biopal MAR not as a measure of absolute productivity, but as an indicator of when nutrient-rich waters and diatom
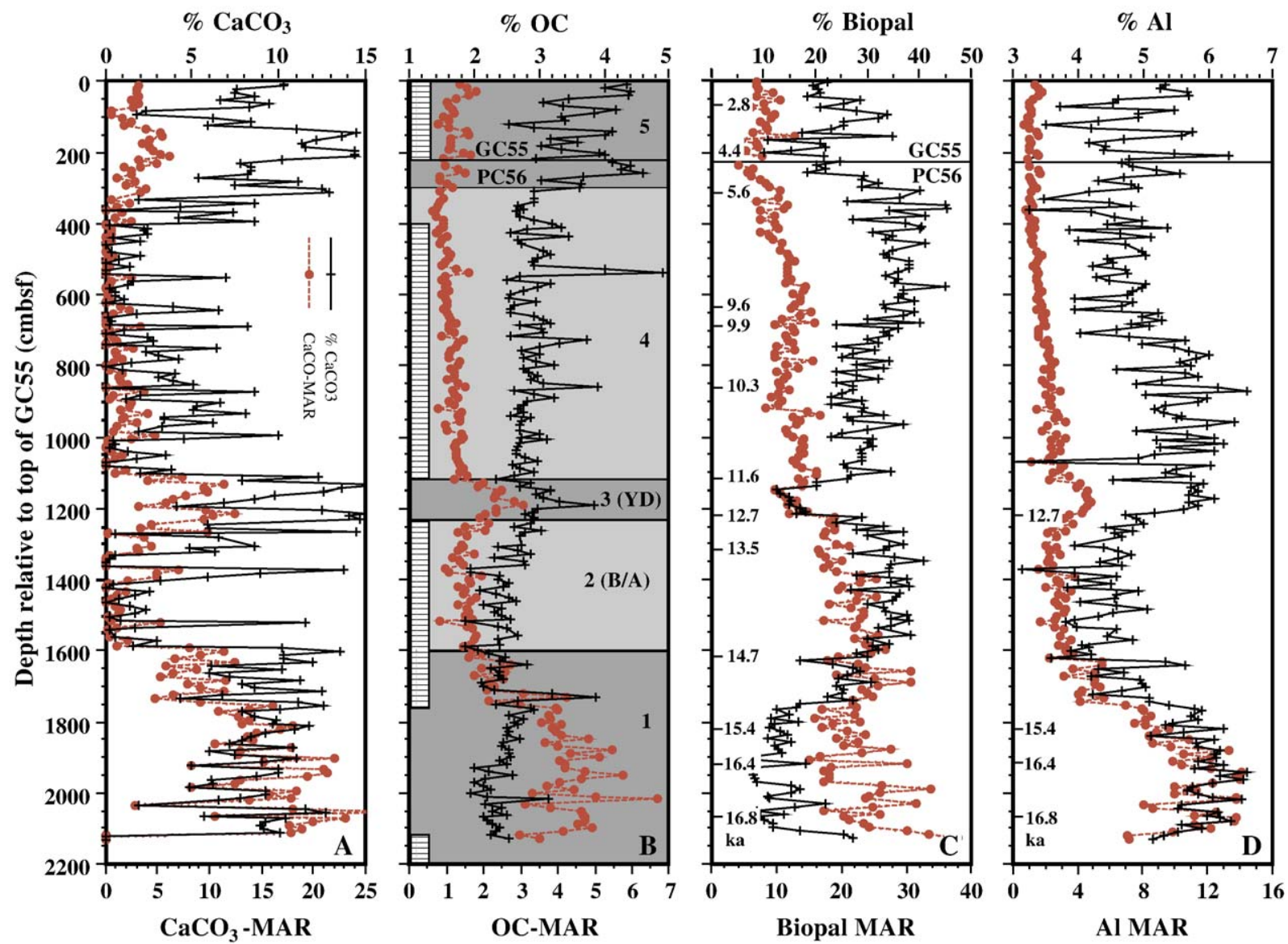

Fig. 2. Profiles of (A) $\mathrm{CaCO}_{3}$ mass accumulation rate (MAR in $\mathrm{g} / \mathrm{cm}^{2} / \mathrm{ky}$ ) and $\% \mathrm{CaCO}_{3}$; (B) OC MAR and $\%$ OC; (C) biopal MAR and $\%$ biopal; and (D) Al MAR and \% Al, all versus depth in centimeters below sea floor (cmbsf) for sediment samples from cores GGC55 and JPC56 from the Guaymas Basin. Stratigraphic locations of laminated sediments are indicated by the laminated box-symbols to the right of the depth scale in (B). The five stratigraphic intervals discussed in text are shown by shading in (B). The stratigraphic positions and values of ${ }^{14} \mathrm{C}$ dates are shown to the right of the depth scale in (C) and (D). 
blooms occurred in the central Gulf. Using this indicator, the laminated sediments have higher biopal contents implying more diatom blooms. However, Sancetta (1995) found that down-core variations in diatom assemblages in JPC56 do not correspond to presence or absence of laminations. She concluded that processes controlling bottom-water oxygen content are not determined by surface-water productivity alone. Because GGC55 and JPC56 were collected from within the OMZ but above the sill depth, the sediments in these cores were subjected to the same oxygen and ventilation properties as those of NPIW in the open Pacific. However, NPIW is further depleted in the Gulf by high carbon fluxes and associated oxygen utilization (Thunell, 1998). Intense diatom blooms in the Gulf may have enhanced the biological oxygen demand imposed on NPIW. Pride et al. (1999) also showed that the laminated sediments have the highest values of $\delta^{15} \mathrm{~N}$, which they interpreted as resulting from increased denitrification in the water column during periods of increased diatom productivity. A similar conclusion was reached by Ganeshram et al. (2000) for laminated sediments on the open slope of NW Mexico off Mazatlan (Fig. 1).

The OC content (Fig. 2B) slowly increases from $2 \%$ at $2000 \mathrm{~cm}$ to $>4 \%$ in the top $300 \mathrm{~cm}$. The $\mathrm{CaCO}_{3}$ content (Fig. 2A) exhibits extreme and abrupt variations, often going from $0 \%$ to $15 \%$ within a few centimeters. Earlier we indicated that the lack of correlation between $\mathrm{OC}$ content and $\mathrm{Cd}$ and $\mathrm{Mo}$ concentrations is highly unusual, but it is also unusual that the laminated sediments (indicated by the pattern on depth scale in Fig. 2B) do not contain the highest OC contents as they do on the Alta California margin (Gardner et al., 1997; Dean et al., 1997; Zheng et al., 2000a), on the NW Mexican margin (Ganeshram and Pedersen, 1998), and on the Baja California Pacific margin (Ortiz et al., 2004).

Based on the variation of the four components plotted in Fig. 2, the section recovered in cores GGC55 and JPC56 was divided into five intervals.

Sediments in Interval $1(1600-220 \mathrm{~cm}, 14.7-17 \mathrm{ka})$ contain some of the lowest biopal contents (10-20\%, Fig. 2C) and highest $\mathrm{CaCO}_{3}$ contents (Fig. 2A). They also contain the highest amount of detrital material, as indicated by the high concentrations and MARs of $\mathrm{Al}$ (Fig. 2D). The sediments in this interval are mostly bioturbated, but some laminated intervals occur at the top and bottom of this interval. Values of $\delta^{15} \mathrm{~N}$ in Interval 1 sediments are the lowest recorded in JPC56 suggesting that the late glacial interval in the Gulf was characterized by enhanced ventilation (Pride et al.,
1999). Enhanced glacial-age ventilation also has been documented on the open margin of northwestern Mexico (Ganeshram and Pedersen, 1998).

The apparent high concentration of detrital material in Interval 1 (high Al concentration) probably is the result of lower dilution of detrital material by the very low concentration of biosiliceous material (low biopal). To compensate for the dilution of detrital material by biopal, as well as by $\mathrm{CaCO}_{3}$ and organic matter, concentrations of $\mathrm{Al}$ were calculated on a nonbiogenic basis (subtracting out the organic-matter, biopal, and $\mathrm{CaCO}_{3}$ fractions). The stratigraphic distribution of $\%$ nonbiogenic $\mathrm{Al}$ is shown in Fig. 3A. This distribution suggests that there was an increase in clastic material about 1200 years ago during the YD.

Sediments in Interval $2(1600-1220 \mathrm{~cm}, 14.7-$ $12.7 \mathrm{ka}$ ) contain high concentrations of biopal $(>30 \%)$ and low concentrations of $\mathrm{CaCO}_{3}$. The sediments in this interval are all laminated, but OC contents are low (2$3 \%$, Fig. 2B). This interval corresponds in time to the global Bölling/Alleröd (B/A) warm period. Intervals of laminated sediment deposited during the $\mathrm{B} / \mathrm{A}$, but with high OC contents, have been observed on the open margin off central California (Zheng et al., 2000a). The $\mathrm{B} / \mathrm{A}$ interval was characterized by high biosiliceous productivity and conditions similar to those of today in both in JPC56 (Barron et al., 2005) and in DSDP 480 (Barron et al., 2004), with most of the production occurring from summer through winter (Sancetta, 1995). Values of $\delta^{15} \mathrm{~N}$ in sediments deposited during the Interval 2 are the highest recorded in JPC56 suggesting extreme denitrification (Pride et al., 1999) and oxygen deficiency.

Sediments in Interval $3(1220-1100 \mathrm{~cm}, 12.7-$ $11.6 \mathrm{ka})$ have very low biopal contents $(<20 \%$, Fig. 2C) and high $\mathrm{CaCO}_{3}$ contents (Fig. 2A). This interval corresponds in age to the global Younger Dryas (YD) cold event. The sediments in this interval are all bioturbated. Pride et al. (1999) suggested that the lack of laminated sediments deposited during the YD interval in JPC56, and lower values of $\delta^{15} \mathrm{~N}$, implying less denitrification, indicate that the OMZ in the Guaymas Basin was better ventilated. Enhanced ventilation during the Younger Dryas also has been observed in the Santa Barbara Basin (Kennett and Ingram, 1995; Behl and Kennett, 1996), and on the open margin off central California (Zheng et al., 2000a). Winter upwelling diatoms are absent in the sediments from Interval 3, but tropical diatoms make up to $70 \%$ of the diatom flora, which, together with higher $\mathrm{CaCO}_{3}$ content (more calcareous plankton), suggests that southeasterly winds with monsoonal moisture dominated the climatic pattern 

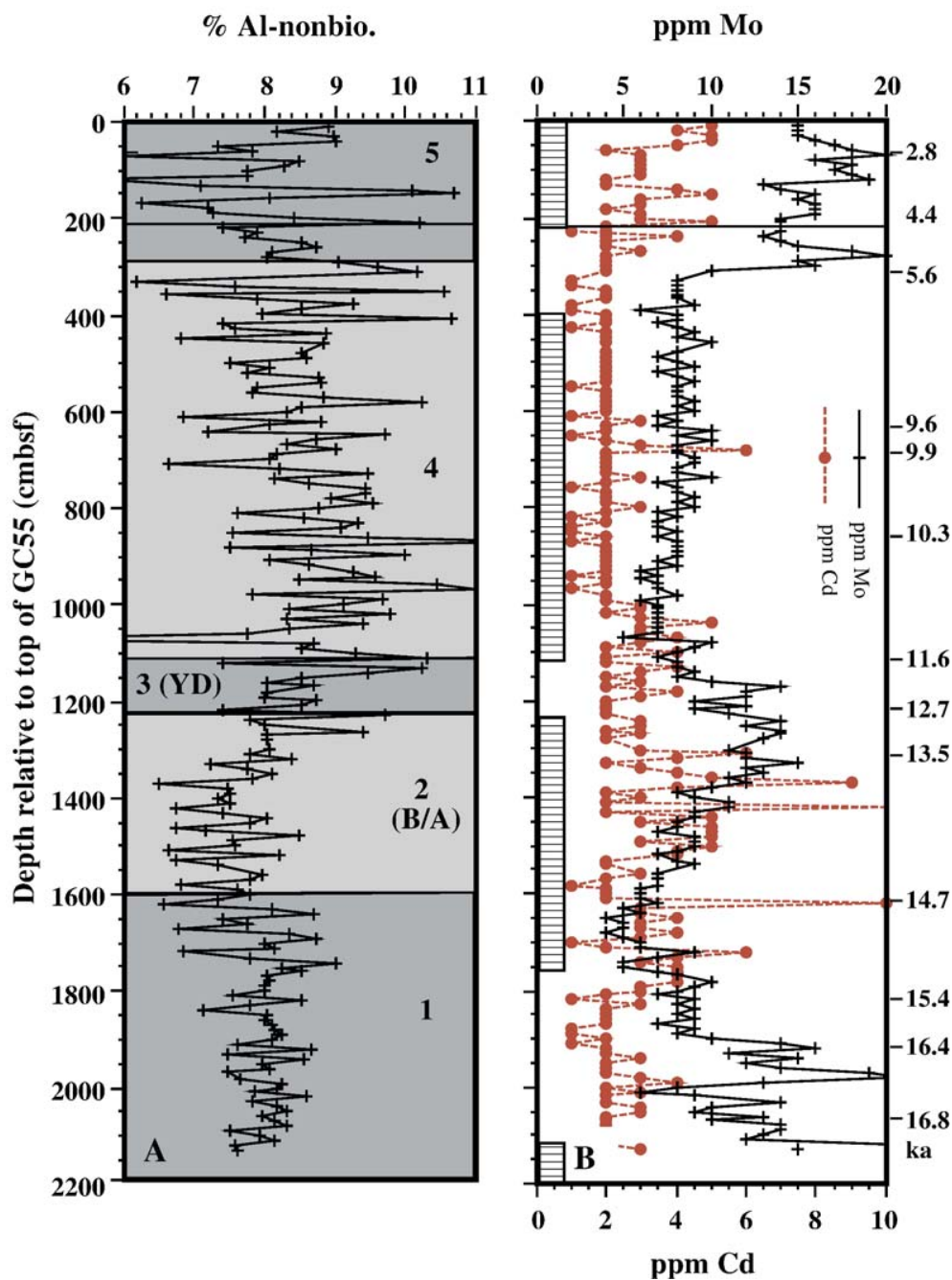

Fig. 3. Profiles of (A) \% nonbiogenic $\mathrm{Al}$ (after subtracting out organic-matter, biopal, and $\mathrm{CaCO}_{3}$ fractions); (B) ppm Cd and ppm Mo, all versus depth in centimeters below sea floor (cmbsf) for sediment samples from cores GGC55 and JPC56 from the Guaymas Basin. Stratigraphic locations of laminated sediments are indicated by the laminated box-symbols to the right of the depth scale in (B). The five stratigraphic intervals discussed in text are shown by shading in (A). The stratigraphic positions and values of ${ }^{14} \mathrm{C}$ dates are shown on the right margin of (B).

during the YD in the Gulf (Barron et al., 2005). Thus, although the YD generally represents colder conditions globally, in the Gulf this interval saw more warm, tropical conditions.

Sediments in Interval $4(1100-300 \mathrm{~cm}, 11.6-5.6 \mathrm{ka})$, like those in Interval 2, generally have high concentrations of biopal $(>30 \%)$ and low concentrations of $\mathrm{CaCO}_{3}$. Tropical diatoms and silicoflagellates are virtually absent from this interval, but winter diatoms are abundant, suggesting that winter-like conditions with northwesterly upwelling winds predominated (Sancetta, 1995; Barron et al., 2005). Most of the sediments in this interval are laminated, and $\mathrm{OC}$ contents average about 3\% (Fig. 2B). The combination of laminated sediments and high concentrations of biopal implies more blooms of upwelling diatoms.

Sediments in Interval $5(300-0 \mathrm{~cm}, 5.6-2.5 \mathrm{ka})$, like those in Interval 3, contain some of the highest sustained $\mathrm{CaCO}_{3}$ contents (Fig. 2A), and the highest OC contents (Fig. 2B). The sediments in the top $200 \mathrm{~cm}$ of Interval 1 are laminated and those in the lower $100 \mathrm{~cm}$ are bioturbated. The OC content of the laminated sediments is high, but the $\mathrm{OC}$ content of the bioturbated sediments is even higher (Fig. 2B). At least some of the higher OC contents of these upper-most sediments are undoubtedly due to incomplete "burndown" (diagenetic oxidation) of fresh, labile organic matter. The age model suggests that 2500 years is missing from the top of GGC55, and that 
missing section probably contained even higher concentrations of labile organic matter. The biopal contents in Interval 5 sediments are generally low $(<30 \%$, Fig. $2 \mathrm{C})$. The organic matter that ultimately accumulates in the sediments is produced by siliceous and calcareous plankton as well as by other plankton with no fossilizable hard parts (e.g., dinoflagellates). The higher OC content of the more calcareous, less siliceous sediments in Interval 5 suggests that more organic matter was being preserved, but not necessarily being produced, in association with calcareous nannoplankton. This difference in organic matter preservation may be an apparent difference due to the so-called "mineral ballasting effect" and "packaging factor" whereby the sinking of organic matter is affected by the density of sinking particle aggregates (Francois et al., 2002). Carbonate plankton have a higher density than siliceous plankton, and tend to be more tightly packaged in fecal pellets so that a higher fraction of exported organic matter associated with carbonate productivity reaches the deep sea (Honjo et al., 1982). Diatom debris is more biodegradable and packaged into larger, looser, less hydrodynamic aggregates that could result in greater remineralization of organic matter exported during bloom events (Francois et al., 2002).

Another possibility is that diatom production occurs as short-term blooms whereas nannoplankton production is spread out over longer time periods. Sedimenttrap studies in the Gulf show that winter diatom production may occur as a sustained event over several weeks, or as a series of short blooms (Sancetta, 1995). Yet another possibility is that the finer calcareous particles, with a higher specific surfaces, protects the organic matter from remineralization and thus may provide a control on OC preservation in sediments (e.g., Hedges and Keil, 1995).

Prior to about $6 \mathrm{ka}$, the biogenic characteristics of sediments on the western slope of the Guaymas Basin (JPC56) and on the eastern slope (DSDP 480; Fig. 1) were very similar (Barron et al., 2005). However, after about $6 \mathrm{ka}$ differences began to appear in both siliceous (diatoms and silicoflagellates) and carbonate $\left(\mathrm{CaCO}_{3}\right)$ components that characterize the present east-west differences in the Guaymas Basin (Barron et al., 2005). After 5.4 ka, \% biopal decreases in JPC56-GGC55 (Fig. 2C) but continues to increase in DSDP 480 (Barron et al., 2004). In JPC56, \% $\mathrm{CaCO}_{3}$ increased markedly at about $6 \mathrm{ka}$ (Fig. 2A) whereas it remained at zero in DSDP 480 (Barron et al., 2004). The decrease in biopal in JPC56-GGC55 after $5.4 \mathrm{ka}$ is accompanied by decreases in upwelling and productivity diatoms and silicoflagellates, but increases in tropical diatoms and silicoflagellates (Barron et al., 2005). All of the calcareous and biosiliceous evidence suggests that Interval 5 has recorded a shift from more winter-like conditions with strong northwesterly winds that produce upwelling and high diatom productivity, to more summer-like conditions with weak southeasterly winds that bring tropical surface water into the Gulf with reduced biosilicerous productivity but increased calcareous productivity. Introduction of warm tropical waters also is indicated by a decrease in $\delta^{18} \mathrm{O}$ of the planktonic foram $N$. pachyderma between 6 and $5 \mathrm{ka}$ (Keigwin, 2002). Warmer, more summer-like conditions in the Gulf suggest that more El Niño-like conditions were established in the eastern equatorial Pacific. Today, warm surface waters of the Gulf in the summer allow monsoonal moisture to move up the Gulf into the southwestern United States (Mitchell et al., 2002).

Sediment-trap and surface-sediment studies on the northwestern Mexican margin (Nameroff et al., 2002) and in the Santa Barbara Basin (Y. Zheng, personal communication, 2004) indicate that most of the $\mathrm{Cd}$ reaching the floor of the ocean in these areas is in the form of nonlithogenic particulates, presumably in organic matter, and to a lesser extent from overlying seawater. These studies indicate that $\mathrm{Cd}$ can be used as a qualitative paleoproductivity indicator, and this proxy has been used as such, along with other paleoproductivity indicators (biopal, $\mathrm{OC}$, and $\mathrm{Ba} / \mathrm{Al}$ ), to show glacial-interglacial changes in productivity on the Mexican, California, and Oregon margins (Nameroff et al., 2004), and on the Pacific margins of Baja and Alta California (Dean et al., 1997; Ortiz et al., 2004). These studies also showed that other trace elements in sediments (e.g., Re, Mo, U, and V), together with the presence of laminated sediments, can be used as indicators of anoxia. The close association of indicators of productivity and anoxia in laminated sediments in the OMZs in these continental margin settings indicates that bottom-water oxygen levels are more closely linked to productivity than to ventilation. Apparently, none of these observations from sediments on open margins apply directly to the Gulf of California, as judged from the sediments recovered in GGC55 and JPC56, and the sediments recovered at DSDP Site 480 on the eastern slope of the Guaymas Basin (Fig. 1; Keigwin and Jones, 1990; Barron et al., 2005).

Throughout most of the section recovered in cores GGC55 and JPC56, elevated concentrations of Mo and $\mathrm{Cd}(>1 \mathrm{ppm})$ bear little relation to each other (Fig. 3B), to intervals of laminated sediment, or to OC (Fig. 2B). The only part of the section where the expected relations seem to apply is in Interval $5(0-300 \mathrm{~cm})$ where 
sediments are laminated and contain high concentrations of OC, Mo, and Cd (Figs. 2B and 3B). Laminated sediments indicate that bottom waters were sufficiently oxygen deficient $(<5 \mu \mathrm{mol} / \mathrm{kg}$; Zheng et al., 2000a) at the time they were deposited to eliminate burrowing organisms. Zheng et al. (2000b) found that in the Santa Barbara Basin authigenic Mo formation (>1 ppm Mo) requires a bottom-water dissolved oxygen concentration of $<3 \mu \mathrm{M}$, but the master variable regulating Mo precipitation is the sulfide concentration in pore waters. A pore-water sulfide concentration of $\sim 0.1 \mu \mathrm{mol} / \mathrm{kg}$ appears to be a threshold for the onset of Mo precipitation (Zheng et al., 2000b).

The qualitative geochemical indicators for higher productivity are high concentrations and MARs of OC and Cd. Sediments deposited during the YD (Interval 3) are bioturbated, suggesting that bottom waters were oxygenated, and sediments deposited during the B/A are laminated, indicating anoxic or nearly anoxic bottom waters. This in line with observations from three cores from the central California margin where some intervals of laminated sediments occur in the $\mathrm{B} / \mathrm{A}$
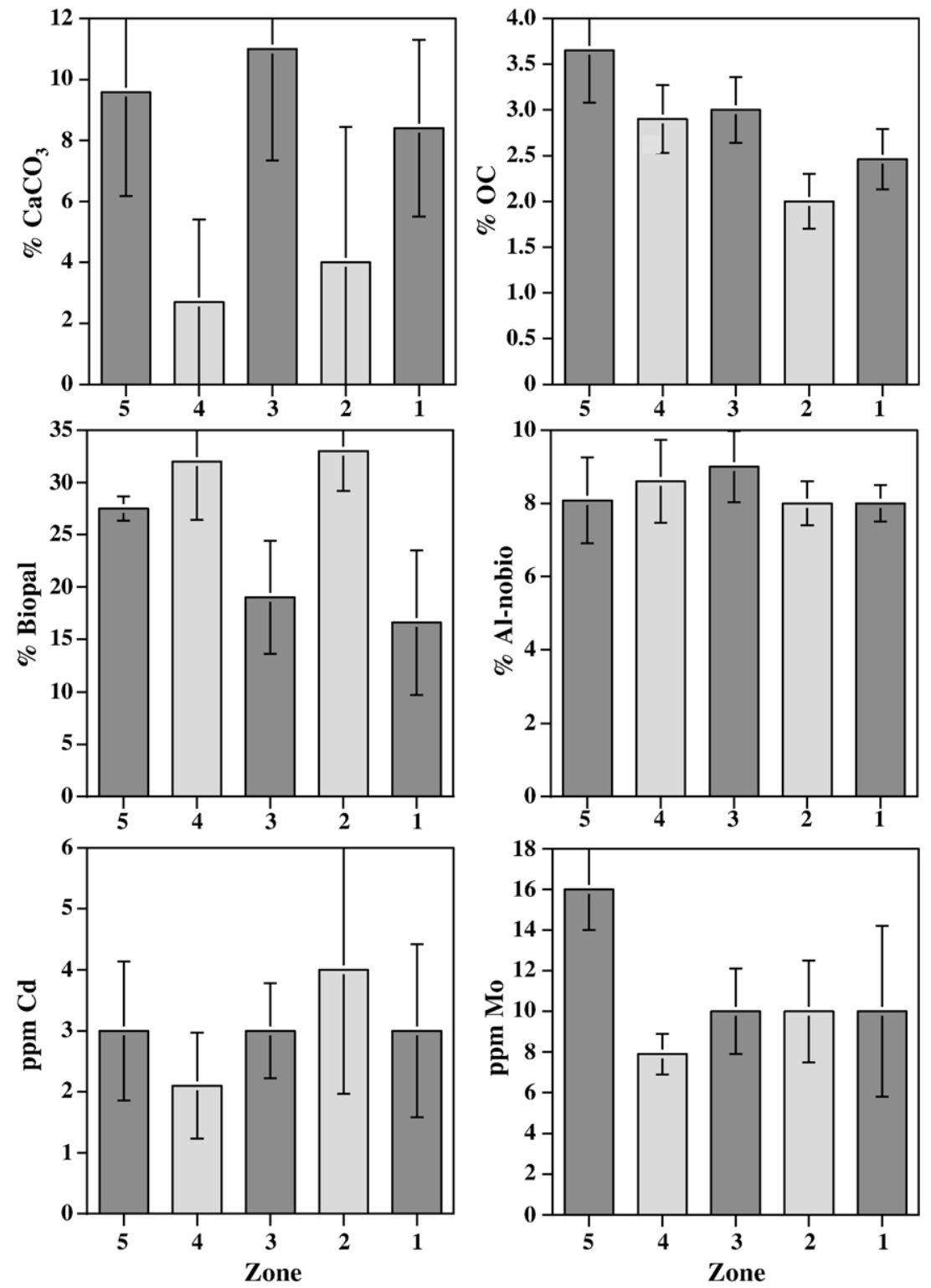

Fig. 4. Histograms of average $\% \mathrm{CaCO}_{3}, \% \mathrm{OC}, \%$ biopal, $\%$ nonbiogenic $\mathrm{Al}$, ppm $\mathrm{Cd}$, and ppm Mo in sediments from the five stratigraphic intervals discussed in text. The error bars at the tops of the histograms represent one standard deviation. 
section whereas YD and Holocene sediments are bioturbated (Dean et al., 1997; Zheng et al., 2000a). However, in those cores the laminated B/A sediments contain elevated concentrations of $\mathrm{Mo}, \mathrm{Cd}$, and $\mathrm{OC}$ indicating anoxia and higher productivity. In JPC56, concentrations of $\mathrm{Cd}$ are elevated in some samples from the $\mathrm{B} / \mathrm{A}$ interval (Interval 2; Fig. 3B) as are concentrations of Mo. There is no trend to high $\mathrm{Cd}$ concentrations in the $\mathrm{B} / \mathrm{A}$ interval (Interval 2); they simply occur randomly in several horizons throughout the interval (Fig. 3B). It is always possible that peaks in any proxy could be do to sediment redeposition (focusing), although there is no way of showing this. For example, Zheng et al. (2000b) found that in the Santa Barbara Basin the flux of $\mathrm{Cd}$ in surface sediments was up to three times the $\mathrm{Cd}$ flux in sediment traps. However, sediment focusing should also produce peaks in other proxies. Concentrations of Mo do show a trend. The increase in Mo begins in the laminated sediments at the top of Interval 1, continues to increase throughout Interval $2(\mathrm{~B} / \mathrm{A})$, and decreases in the bioturbated sediments of Interval 3 (YD; Fig. 3B). Perhaps bottom waters became sufficiently deficient in DO before the $\mathrm{B} / \mathrm{A}$ to eliminate burrowing organisms and permit the preservation of laminated sediments. Then, a threshold in sulfate reduction in the sediments was reached that resulted in the precipitation of hydrogenous Mo. Sulfate reduction intensified throughout the $\mathrm{B} / \mathrm{A}$ causing the formation of more hydrogenous Mo. Zheng et al. (2000b) concluded that the accumulation rate of organic matter, the fuel for sulfate reduction, was as important for Mo precipitation as sulfide concentration, and perhaps more so. This may be true for the Santa Barbara basin, and probably for most other anoxic environments on the planet, but it does not appear to be true for the Gulf of California. I conclude, as have others (e.g., Sancetta, 1995; Keigwin, 2002), that we do not fully understand what is controlling the preservation of laminated sediments, as well as elevated concentrations of $\mathrm{Mo}$ and $\mathrm{Cd}$ in sediments of the Gulf of California, but it is not simply anoxia and productivity.

The geochemical characteristics of the five intervals can be summarized by mean concentrations of selected key variables in each of the intervals. These summary means are illustrated as histograms in Fig. 4. Certainly, the most obvious differences are the higher $\mathrm{CaCO}_{3}$ contents in sediments of Intervals 1, 3, and 5, and the higher biopal contents in sediments of Intervals 2 and 4 . This must represent a shift in phytoplankton populations from tropical, calcareous nannoplankton to winter, upwelling diatoms. An increase in calcareous nannoplankton probably represents an increase in influx of southern-sourced, tropical Pacific surface water. Sancetta (1995) and Barron et al. (2005) found that sediments in JPC56 that had the highest abundances of calcareous nannoplankton in Intervals 1 and 3 (high concentrations of $\mathrm{CaCO}_{3}$, Fig. 2A). These intervals also had the highest abundances of the El Niño-indicating diatom Azpeitia nodulifera.

Although there appears to be a change in source of terrigenous clastic material after the YD interval (Interval 3), as evidenced by an increase in \% nonbiogenic $\mathrm{Al}$ (Fig. 3A), Fig. 4 shows that the average change in nonbiogenic $\mathrm{Al}$ between intervals is not very large. The concentration of OC generally increased throughout the Holocene (Interval 5; Figs. 2B and 4), which, together with increasing biopal, suggest that productivity increased in the western Guaymas Basin throughout the Holocene, particularly over the last 5.6 ky (Interval 5), resulting in more persistent bottomwater anoxia (highest Mo; Figs. 3B and 4). Concentrations of Cd also increased in Interval 5 (Fig. 3B) perhaps indicating higher productivity, but concentrations were not as high as in laminated sediments deposited during Interval 2 (B/A; Fig. 4). Late Holocene diatom assemblages in JPC56 indicated to Sancetta (1995) that there was high productivity during both winter and spring seasons.

\section{Conclusions}

1. Sediments in the Guaymas Basin are predominantly mixtures of biopal and one or more detrital clastic components, with minor organic matter and $\mathrm{CaCO}_{3}$, the latter being highly variable.

2. The trace elements $\mathrm{Cd}$ and Mo, whose concentrations commonly are elevated in OC-rich, anoxic sediments, are not associated with the organic fraction and do not have particularly high concentrations in laminated sediments, which is highly unusual. This is unlike the open Pacific margins of the Californias, and most other continental margins of the world with well-developed oxygen minimum zones, where elevated concentrations of $\mathrm{OC}, \mathrm{Mo}, \mathrm{Cd}$, and other redox-sensitive elements occur in laminated sediment. It is not clear what is controlling the preservation of laminated sediments and elevated concentrations of OC and metals in sediments of the Gulf of California, but it is not simply anoxia and productivity.

3. Based on the variation of the two major sediment components (biopal and detrital clastic material), and two minor components $\left(\mathrm{CaCO}_{3}\right.$ and organic matter), the section recovered in cores GGC55 and JPC56 
was divided into five intervals. Sediments in Interval $1(14.7-17 \mathrm{ka})$ contain some of the lowest biopal contents $(10-20 \%)$ and highest $\mathrm{CaCO}_{3}$ contents. They also contain the highest amount of detrital material. The sediments in this interval are all mostly bioturbated. Sediments in Interval $2(12.7-14.7 \mathrm{ka})$, contain high concentrations of biopal $(>30 \%)$ and low concentrations of $\mathrm{CaCO}_{3}$. The sediments in this interval are all well laminated, but $\mathrm{OC}$ contents are low $(2-3 \%)$. This interval corresponds in time to the global Bölling/Alleröd (B/A) warm period. Interval 3 sediments $(11.6-12.7 \mathrm{ka})$ contain high $\mathrm{CaCO}_{3}$ contents and low biopal contents but are not laminated. They record warm, tropical surface waters in the Gulf, but were deposited during the YD global cold interval. Sediments in Interval 4 (5.6 to $11.6 \mathrm{ka}$ ), like those in Interval 2, have low $\mathrm{CaCO}_{3}$ contents and high biopal contents, and record climatic conditions characterized by strong northwesterly winds, high biosiliceous production and low carbonate production. Most of the sediments in this interval are laminated, and OC contents average about 3\%. Interval 5 sediments ( 2.5 to $5.6 \mathrm{ka}$ ) have high $\mathrm{OC}$ and $\mathrm{CaCO}_{3}$ contents and low biopal contents, and appear to have recorded a shift from more winter-like conditions, to more summer-like conditions with weak southeasterly winds that bring warm, tropical Pacific surface water into the Gulf with reduced biosiliceous productivity but increased calcareous productivity. Most of the sediments in this interval are laminated with an average OC content of 3.7\%. This is the only interval where elevated concentrations of $\mathrm{Cd}$ and $\mathrm{Mo}$ are clearly associated with laminated sediments, and high concentrations of OC and other indicators of high productivity.

\section{Acknowledgements}

This work was supported by the USGS Earth Surface Dynamics Program. I thank Lloyd Keigwin, John Barron, and one anonymous reviewer for helpful comments. [LW]

\section{References}

Baba, J., Peterson, C.D., Schrader, H.J., 1991. Modern fine-grained sediments in the Gulf of California, 1991a. In: Dauphin, J.P., Simoneit, B.R.T. (Eds.), The Gulf and Peninsular Province of the Californias. . Am. Assoc. Petrol. Geol. Mem., vol. 47. American Association of Petroleum Geologists, Tulsa, OK, pp. 569-587.

Barron, J.A., Bukry, D., Bischoff, J.L., 2004. High resolution paleoceanography of the Guaymas Basin, Gulf of California, during the past 15000 years. Mar. Micropaleontol. 50, 185-207.
Barron, J.A., Bukry, D., Dean, W.E., 2005. Paleoceanographic history of the Guaymas Basin, Gulf of California, during the past 15,000 years based on diatoms, silicoflagellates, and biogenic sediments. Mar. Micropaleontol. 56, 81-102.

Baumgartner, T.R., Ferreira-Bartrina, V., Moreno-Hentz, P., 1991. Varve formation in the central Gulf of California: a reconsideration of the origin of the dark laminae from the 20th century varve record. In: Dauphin, J.P., Simoneit, B.R.T. (Eds.), The Gulf and Peninsular Province of the Californias. . Am. Assoc. Petrol. Geol. Mem., vol. 47. American Association of Petroleum Geologists, Tulsa, OK, pp. 617-635.

Behl, R.J., Kennett, J.P., 1996. Brief interstadial events in the Santa Barbara Basin, NE Pacific, during the past $60 \mathrm{kyr}$. Nature 379 , 243-246.

Bray, N.A., 1988. Watermass formation in the Gulf of California. J. Geophys. Res. 93, 9223-9240.

Briggs, P.H., 2002. The determination of forty elements in geological and botanical samples by inductively coupled plasma-atomic emission spectrometry. In: Taggart, J.E. (Ed.), Analytical Methods for Chemical Analyses of Geologic and Other Materials. U.S. Geol. Survey Open-File Rept. 02-223, pp. G1-G20.

Bruland, K.W., 1983. Trace elements in seawater. In: Riley, J.P., Chester, R. (Eds.), Chemical Oceanography, vol. 8. Academic Press, pp. 157-220.

Brumsack, H.J., 1986. The inorganic geochemistry of Cretaceous black shales (DSDP Leg 41) in comparison to modern upwelling sediments from the Gulf of California. In: Summerhayes, C.P., Shackleton, N.J. (Eds.), North Atlantic Paleoceanography: Geological Society of London, Spec. Pub., vol. 21, pp. 447-462.

Calvert, S.E., 1966. Origin of diatom-rich, varved sediments from the Gulf of California. J. Geol. 76, 546-565.

Chester, R., 1990. Marine Chemistry. Unwin Hyman, London. 698 pp.

Collier, R., Edmond, J., 1984. The trace element chemistry of marine biogenic particulate matter. Prog. Oceanogr. 13, 113-119.

Crusius, J., Calvert, S., Pedersen, T., Sage, D., 1996. Rhenium and molybdenum enrichments in sediments as indicators of oxic, suboxic, and sulfidic conditions of deposition. Earth Planet. Sci. Lett. 145, 65-78.

Dean, W.E., Gardner, J.V., Piper, D.Z., 1997. Inorganic geochemical indicators of glacial-interglacial changes in productivity and anoxia on the California continental margin. Geochim. Cosmochim. Acta 61, 4507-4518.

Emerson, S.R., Huested, S.S., 1991. Ocean anoxia and concentrations of molybdenum and vanadium in seawater. Mar. Chem. 34, 177-196.

Engleman, E.E., Jackson, L.L., Norton, D.R., Fischer, A.G., 1985. Determination of carbonate carbon in geological materials by coulometric titration. Chem. Geol. 53, 125-128.

Francois, R., Honjo, S., Krishfield, R., Manganini, S., 2002. Factors controlling the flux of organic carbon to the bathypelagic zone of the ocean. Glob. Biogeochem. Cycles 16, 1087, doi:10.1029/ $2001 \mathrm{~GB} 001722$.

Ganeshram, R.S., Pedersen, T.F., 1998. Glacial-interglacial variability in upwelling and bioproductivity off NW Mexico: implications for quaternary paleoclimate. Paleoceanography 13, 634-645.

Ganeshram, R.S., Pedersen, T.F., Calvert, S.E., McNeill, G.W., Fontugne, M.R., 2000. Glacial-interglacial variability in denitrification in the world's oceans: causes and consequences. Paleoceanography 15, 361-376.

Gardner, J.V., Dean, W.E., Dartnell, P., 1997. Biogenic sedimentation beneath the California Current system for the past $30 \mathrm{ky}$ and its paleoceanographic significance. Paleoceanography 12, 207-225. 
Hedges, J.I., Keil, R.G., 1995. Sedimentary organic matter preservation: an assessment and speculative synthesis. Mar. Chem. 49, $81-115$.

Honjo, S., Manganini, S.J., Cole, J.J., 1982. Sedimentation of biogenic matter in the deep ocean. Deep-Sea Res., Part I 29, 609-625.

Jacobs, L., Emerson, S., Skei, J., 1985. Partitioning and transport of metals across the $\mathrm{O}_{2} / \mathrm{H}_{2} \mathrm{~S}$ interface in a permanently anoxic basin, Framvaren Fjord, Norway. Geochim. Cosmochim. Acta 49, $1433-1444$.

Keigwin, L.D., 2002. Late Pleistocene-Holocene paleoceanography and ventilation of the Gulf of California. J. Oceanogr. 58, 421-432.

Keigwin, L.D, Jones, G.A., 1990. Deglacial climatic oscillations in the Gulf of California. Paleoceanography 5, 1009-1023.

Kennett, J.P., Ingram, B.L., 1995. Paleoclimatic evolution of Santa Barbara Basin during the last 20k.y.: marine evidence from Hole 893A. In: Kennett, J.P., Baldauf, J.G., Lyle, M. (Eds.), Proceed. Ocean Drilling Prog., Sci. Results, vol. 146 (Pt. 2), pp. 309-325.

Mitchell, D.L., Ivanova, D., Rabin, R., Redmond, K., Brown, T.J., 2002. Gulf of California sea surface temperatures and the North American monsoon: mechanistic implications from observations. J. Climate 15, 2261-2281.

Moore, D.G., 1973. Plate-edge deformation and crustal growth, Gulf of California structural province. Geol. Soc. Amer. Bull. 84, 1883-1906.

Nameroff, T.J., Balistrieri, L.S., Murray, J.W., 2002. Suboxic trace metal geochemistry in the eastern tropical North Pacific. Geochim. Cosmochim. Acta 66, 1139-1158.

Nameroff, T.J., Calvert, S.E., Murray, J.W., 2004. Glacial-interglacial variability in the eastern tropical North Pacific oxygen minimum zone recorded by redox-sensitive trace metals. Paleoceanography 19, A1010, doi:10.1029/2003PA000912.

Ortiz, J., OConnell, S.E., DelViscio, J., Dean, W.E., Carriquiry, J.D., Marchitto, T., Zheng, Y., van Geen, A., 2004. Enhanced marine productivity off western North America during warm climatic intervals of the past $52 \mathrm{ka}$. Geology 32, 521-524.
Piper, D.Z., 1994. Seawater as the source of minor elements in black shales, phosphorites, and other sedimentary deposits. Chem. Geol. 114, 95-114.

Piper, D.Z., Dean, W.E., 2002. Trace-element deposition in the Cariaco Basin under sulfate reducing conditions - a history of the local hydrography and global climate, $20 \mathrm{ka}$ to the present. U.S. Geol. Surv. Prof. Paper 1670 (41 pp.).

Pride, C., Thunell, R., Sigman, D., Keigwin, L., Altabet, M., Tappa, E., 1999. Nitrogen isotopic variations in the Gulf of California since the last deglaciation. Response to global climate change. Paleoceanography 14, 397-409.

Sancetta, C., 1995. Diatoms in the Gulf of California: seasonal flux patterns and the sediment record for the last 15,000years. Paleoceanography 10, 67-84.

Schrader, H., Baumbartner, T., 1983. Decadal variation of upwelling in the central Gulf of California. In: Thiede, J., Suess, E. (Eds.), Coastal Upwelling, Its Sediment Record: Part B. Sedimentary Records of Ancient Coastal Upwelling. Plenum Press, New York, pp. 247-276.

Thunell, R.C., 1998. Seasonal and annual variability in particle fluxes in the Gulf of California: a response to climate forcing. Deep-Sea Res., Part I 45, 2059-2083.

Thunell, R.C., Pride, C.J., Tappa, E., Muller-Karger, F.E., 1994. Biogenic silica fluxes and accumulation rates in the Gulf of California. Geology 22, 303-306.

Wedepohl, K.H., 1995. The composition of the continental crust. Geochim. Cosmochim. Acta 59, 1217-1232.

Zheng, Y., van Geen, A., Anderson, R.F., Gardner, J.V., Dean, W.E., 2000a. Intensification of the northeast Pacific oxygen minimum zone during the Bölling-Alleröd warm period. Paleoceanography $15,528-536$.

Zheng, Y., Anderson, R.F., van Geen, A., 2000b. Authigenic molybdenum formation in marine sediments: a link to porewater sulfide in the Santa Barbara Basin. Geochim. Cosmochim. Acta 64, 4165-4178. 